South African Journal of Geomatics, Vol. 7. No. 3, November 2018

\title{
The application of an Urban Sprawl Index: comparing towns and cities in the Western Cape Province, South Africa
}

\author{
Anele Horn, Amanda Van Eeden \\ Centre for Regional and Urban Innovation and Statistical Exploration, University of Stellenbosch
}

DOI: $\underline{\text { http://dx.doi.org/10.4314/sajg.v7i3.4 }}$

\begin{abstract}
The incidence and effects of urban sprawl have been the subject of a great many academic research mainly as a result of the challenges posed by continued urbanisation, especially in developing countries (see inter alia Jenks, Kozak and Takkanon 2008; Mander, Brebbia and Tiezzi 2006; Jenks and Burgess 2000; and Soja 2000). South Africa witnessed a proliferation of legislation and spatial policies to limit urban sprawl and contain the physical expansion and development of urban areas during the last two decades in response to exponential post-apartheid urbanization. In 2005, the Provincial Spatial Development Framework of the Western Cape Province, South Africa stated that "an Urban Edge shall be drawn around all villages, towns and cities in the province with the primary function to contain outward growth of urban settlements" (City of Cape Town, 2009) and in parallel the Provincial Department of Environmental Affairs and Development Planning published the Western Cape Urban Edge Guideline document assisting all municipalities in the province to delineate urban edges to be included in municipal Spatial Development Frameworks (SDF) thereby illustrating intent on maintaining urban footprints that are compact and limit developments that could be considered urban sprawl. Subsequently municipal urban edges have been delineated and are presently reflected in most municipal Spatial Development Frameworks in the province. This paper presents an Urban Sprawl Index as a tool to comparatively analyse the extent of urban sprawl between cities and towns of different sizes, making use of cadastre, land use and population data over time. The Urban Sprawl Index (USI) for the Western Cape put forward by this research will enable the comparative measurement of the extent of urban sprawl proportionately between the Metropolitan and local municipalities in the province and thereby aid in understanding the impact of planning instruments such as urban edges in the context of development dynamics and pressures experienced by individual cities.
\end{abstract}

\section{Introduction}

The incidence and effects of urban sprawl have been the subject of a great many academic research mainly as a result of the challenges posed by continued urbanisation, especially in developing countries (see inter alia Jenks, Kozak and Takkanon 2008; Mander, Brebbia and Tiezzi 2006; Jenks and Burgess 2000; and Soja 2000). South Africa witnessed a proliferation of legislation and spatial policies to limit urban sprawl and contain the physical expansion and development of urban areas 
during the last two decades in response to exponential post-apartheid urbanization (at a National legislative level see inter alia the Development Facilitation Act (1995), the National Development Plan (2013) and the Integrated Urban Development Framework (2016)), but the measurement of the successes or failures of these instruments has remained a largely unattainable goal. This can be attributed to the multifaceted nature of urban sprawl, the unavailability of comparable data over a reasonable time-period, and the absence of an appropriate measure of proportionate comparison. This argument is aided by authors such as Du Plessis et al (2015) who noted the surprising paucity of comprehensive cross city comparative empirical evidence to evaluate the changes of South African city structure since 1994 that would enable critical reflection on the impact of new generation spatial policy and planning instruments. In 2005, the Provincial Spatial Development Framework of the Western Cape Province, South Africa stated that "an Urban Edge shall be drawn around all villages, towns and cities in the province with the primary function to contain outward growth of urban settlements” (City of Cape Town, 2009) and in parallel the Provincial Department of Environmental Affairs and Development Planning published the Western Cape Urban Edge Guideline document assisting all municipalities in the province to delineate urban edges to be included in municipal Spatial Development Frameworks (SDF) thereby illustrating intent on maintaining urban footprints that are compact and limit developments that could be considered urban sprawl, in line with afore mentioned national policies. Subsequently municipal urban edges have been delineated and are presently reflected in most municipal Spatial Development Frameworks in the province. This paper presents an Urban Sprawl Index as a tool to comparatively analyse the extent of urban sprawl between cities and towns of different sizes, making use of cadastre, land use and population data over time. The Urban Sprawl Index (USI) for the Western Cape put forward by this research will enable the comparative measurement of the extent of urban sprawl proportionately between the Metropolitan and local municipalities in the province in an attempt to understand the impact of planning instruments such as urban edges in the context of development dynamics and pressures experienced by individual cities.

\section{Background}

In South Africa, as a result of the spatial political history of Apartheid, urban areas acquired a spatial form that contributed to the formation of single-core cities with far reaching and widespreading peripheral development, either in the form of suburban development or as a result of postApartheid programmes such as the Reconstruction and Development Programme (1994) which, in an attempt to assist the immediate housing shortage, favoured the establishment of single dwelling residential units for low income communities, on single plots on affordable land at the urban periphery (Horn, 2010). This invariably contributed to urban sprawl and even though this programme has since been abandoned, the trend towards low density residential development continues in South African urban areas, and is greatly exacerbated by the continuous accretion of informal dwellers of in-migrants at the urban fringe (Harrison et al 2008). The concepts of compaction and densification of urban form became entrenched in the South African spatial planning policy and approach since 
early 1990s and can be viewed as a key element of the overarching South African spatial planning doctrine (Du Plessis et al., 2015).

The research area for this paper is the Western Cape Province in South Africa, which in all aspects exhibit the spatial challenges described above (see Sinclair-Smith, 2014, Turok and Watson, 2001 and Haferburg and Obenbrugge, 2003). The province consists of one Metropolitan Municipality (The City of Cape Town), and five district municipalities, which in turn accounts for twenty four local municipalities. The development economy of municipalities are seen as contributing to the perceived urban sprawl i.e. according to the Provincial Urban Edge Guideline (2005)

"The income derived from high income market development, through rates and taxes, must pay for the cost of free services and relatively high service infrastructure maintenance cost in the subsidy and low income residential areas. Thus, the municipalities promote high-income market sector growth, regardless of the environmental and indirect cost thereof."

The City of Cape Town has traditionally been the main receiver of in-migrants from other provinces, especially from the Eastern Cape, both from poorer families seeking proximity to employment markets and from more affluent pensioners seeking proximity to environmental assets (Eigelaar-Meets 2018). Both these trends have contributed to the expansion of population in other local municipalities in the province as well. A study by Jacobs et al (2016) evaluating the patterns and characteristics of substream migrants to the Western Cape found that more than $30 \%$ of migrants to the Western Cape settle either informally, and more than $21 \%$ settle informally in a backyard (21.9\%). The City of Cape Town was a pioneer in delineating an urban edge around its urban footprint and publishing an urban edge policy as early as 2001 with the aim of 1) protecting valuable natural assets against encroachment of development and 2) guard against expansive land development practices and aid the city in achieving a more compact urban form. The City's urban edge policy have since been endorsed in the City's Spatial Development Framework and presently remains as a spatial strategy in the SDF despite being challenged by private and public sector development initiatives specifically in areas such as the Philippi Horticultural Area, as well as the north-western and northeastern extremities of the City's municipal area. In 2005 the Western Cape Department of Environmental Affairs and Development Planning (DEADP) mandated the delineation of an urban edge around the urban footprints of all local municipalities in the province, assisting municipalities in delineating these edges via the Western Cape Urban Edge Guidelines (2005). The Western Cape Urban Edge Guidelines states that "large low income settlements are being placed on the urban edges, placing unattainable demands on service providers, and gated communities are developing in rural areas where leapfrogging causes further pressure on the environment” (DEADP, 2005:2).

\section{Methods in measuring urban sprawl}

The measurement, quantification and modelling of urban sprawl have remained evasive objectives mainly as a result of the absence of a universal definition of what constitutes sprawl (see Bhatta et al., 2010 and Wang et al, 2018). Soja (2000) in studying the landscape of the "postmetropolis" 
recognises five characteristics prominent to urban sprawl as 1) a scattered and discontinuous pattern of development 2) development of residential areas with low densities 3) commercial strip development 4) segregation of land uses and 5) low accessibility and high dependency on private transport. In summary sprawl is an urban growth pattern with the features of low density dispersion, auto-mobile dependence and other environmental and social effects. The direct consequence of sprawl is change in land-use and land-cover of the region as sprawl induces the increase in built-up and paved area (see Bhatta et al., 2010). Sutton (2003) charges the term urban sprawl as merely a politically correct means of complaining about the negative consequences of population growth or the changing scale of the total population of the city they live in. The fact is that the general known impacts of sprawl have been well defined however uncertainty remains regarding an unequivocal definition thereof and how to measure it. Empirical studies contribute to an understanding of the essence of sprawl as it adds quantitative knowledge into the discussion and suggests possible solutions without which ideological and practical discussion on urban sprawl and the effectiveness of a growth management policy remains only conceptual. Spatial metrics can thereby assist in quantifying indices to describe structures and patterns of a landscape (Frenkel et al., 2008). Commonly used spatial indices include growth rates such as population growth rate measured against built-up growth rate (ibid) which calculates quite an "absolute” scale i.e. it creates a black and white distinction between a sprawled city and a compact city (Bhatta et al., 2010), assuming a predetermined threshold. Some theorists experimented with more relative measures that in contrast quantify several attributes of urban growth (see Feng et al, 2014 and Gao et al., 2016) and can be compared among cities, however the complexity of the selection of indicators and data/resource availability renders such an approach expensive and time consuming.

Notwithstanding the discussion on measuring sprawl in literature, the absence of empirical evidence is still clear. Aside from the ambiguous definition of urban sprawl and the difficulties it generate in measuring its scope, another problem with most of the available sprawl measurement scales is the failure to define the threshold between what discerns a sprawling from a non sprawling urban area. Even so, relative comparisons between cities of different sizes and forms could already assist in providing some insight with regards to the occurrence of "more" or "less" sprawl per city.

\section{Methodology}

In a study by Donaldson et al (2012) ten local (non-metropolitan) municipalities in the Western Cape have been identified as having the greatest potential for future growth and development. The study presents an index of different aspects that contribute towards a town or city's development potential that relates inter alia to availability of infrastructure, social capital and economic growth. In this regard the local municipalities of Drakenstein, Stellenbosch, George, Mosselbay, Overstrand, Knysna, Swartland, Saldanah Bay, Breede Valley, and Cape Agulhas were identified as having the highest composite development potential in the Western Cape. This study aimed to use the main urban area/town in the municipalities identified in the aforementioned study as having medium to 
high development potential as well as the City of Cape Town Metropolitan Municipality as subjects of analysis. Based on the immediate availability of data over a measurable time period, the municipalities that were investigated were Drakenstein local municipality, George, Overstrand local municipality, Plettenbergbay, Knysna local municipality and the City of Cape Town metropolitan municipality. The table below provides a summary of the municipalities that form part of this study and the spatial instruments referenced in their respective SDFs that would encourage the prevention of urban sprawl and contribute to a more compact urban form:

Table 1 Municipal spatial instruments contributing to urban compaction

\begin{tabular}{|c|c|c|c|}
\hline Municipality & $\begin{array}{l}\text { Urban } \\
\text { Edge }\end{array}$ & $\begin{array}{l}\text { Densification } \\
\text { strategy }\end{array}$ & Other \\
\hline $\begin{array}{l}\text { City of Cape Town Metropolitan } \\
\text { Municipality }\end{array}$ & $\sqrt{ }$ & $\sqrt{ }$ & Integrated Bus Rapid Transit \\
\hline $\begin{array}{l}\text { Drakenstein local municipality } \\
\text { (Paarl and Wellington) }\end{array}$ & $\sqrt{ }$ & $\sqrt{ }$ & Mixed use infill development \\
\hline George local municipality (George) & $\sqrt{ }$ & $\sqrt{ }$ & Protection of rural areas \\
\hline Knysna local municipality (Knysna) & $\sqrt{ }$ & $\sqrt{ }$ & $\begin{array}{l}\text { No other explicit policies directly } \\
\text { contributing towards compaction }\end{array}$ \\
\hline $\begin{array}{l}\text { Overstrand local municipality } \\
\text { (Hermanus) }\end{array}$ & $\sqrt{ }$ & $\sqrt{ }$ & $\begin{array}{l}\text { Agricultural enhancement and } \\
\text { protection }\end{array}$ \\
\hline
\end{tabular}

Given the complexities of measuring sprawl discussed in the previous section, simple metrics that are capable of black and white characterisation of sprawl such as metrics reflecting the relationship between population change and land conversion to urban uses are preferred methods in aiding research on urban sprawl. A hypothetical black and white determination approach is, if the built-up growth rate exceeds the population growth rate, there is an incidence of sprawl. The data required to develop a measure of urban sprawl (Sutton 2003) are simply 1) the aerial extent of the urban area, 2) the corresponding population of the urban area and 3) a formula describing the relationship between the population and the aerial extent of the urban area. In application of this method most urban sprawl indices make use of remote sensing and satellite data, however, built-up areas that are occupied by residential housing units and their related growths are not easily identifiable from remote sensing data (Sutton, 2003)

For the purposes of arriving at an urban sprawl index (USI) for Western Cape Province, the unit of investigation was initially defined as only the existing residential built-up area inside the municipal border of the city, since the aim of urban edges are generally to curb the expansion of formal development that results in additional land consumption. The 'residential land use' category (i.e. formal residential land use) and the 'township' land use category (i.e. established township areas as per land use data obtained from Mapable (ltd)) were used in calculating the urban areas for two 
reference years as these areas are the ones where increased population were assumed to be accommodated.

In the metropolitan area of Cape Town, the urban footprint covers close to the entire municipal area and therefore the total population was applied. In the case of the four other municipalities, the municipal area consist of a main urban centre as well as a number of smaller towns scattered across the area of jurisdiction of the municipality. In this instance, only the main central urban area's population figures were applied to the USI equation and not that of the isolated and scattered rural settlements. To compute the USI (Equation 1, a and b) the research makes use of South African census data for reference years 1996 and 2011 to ascertain the extent of population growth. The availability of land use data over a comparative time period was the biggest constraint to the research and the closest corresponding reference years for land cover changes were for 1990 and 2014. Given these parameters the USI was calculated using the formula described by Gao et al (2016):

$$
U S I_{T 1 T 2}=C A G R_{T 1 T 2}^{U A}-C A G R_{T 1 T 2}^{U P}
$$

Where: $U S I_{T 1 T 2}$ is the USI for a city measured over time period 1 T1 (1996) and time period 2 T2 (2009);

$C A G R_{T 1 T 2}^{U A}$ are the compound annual growth rate for urban formal residential expansion; $C A G R_{T 1 T 2}^{U P}$ the compound annual growth rate for urban population ;

Equation 1 was obtained by calculating the compound annual growth rate as follows:

$$
C A G R_{T 1 T 2}^{U A}=\left[\left(U A_{T 2} \div U A_{T 1}\right)^{1 /(T 2-T 1)}-1\right] \times 100
$$

and

$$
C A G R_{T 1 T 2}^{U P}=\left[\left(U P_{T 2} \div U P_{T 1}\right)^{1 / T 2-T 1}-1\right] \times 100
$$

Where: $U A_{T 2}$ and $U A_{T 1}$ refer to the urban residential area for a city in $T 1$ and $T 2$ and $U P_{T 2}$ and $U P_{T 1}$ are the urban population for each city in $T 1$ and $T 2$.

For the purpose of this research urban sprawl is defined as a land development pattern that occurs when the rate of residential expansion exceeds the urban population growth rate i.e. USI $\geq 0$.

\section{Results and discussion}

Table 2 presents the initial results following comparative analysis between population growth rate and existing residential footprints in all five municipalities under consideration. 
Table 2: USI calculated for population growth measured against existing residential area for two reference years

\begin{tabular}{|c|c|c|c|c|c|c|}
\hline & Area 1990 & $\begin{array}{l}\text { Population } \\
1996\end{array}$ & Area 2014 & $\begin{array}{l}\text { Population } \\
2011\end{array}$ & USI & $\begin{array}{l}\text { Growth } \\
\text { Factor }\end{array}$ \\
\hline $\begin{array}{l}\text { Cape Town } \\
\text { Metropolitan } \\
\text { Municipality }\end{array}$ & 34560 & 2563095 & 37408 & 3740026 & -2.22 & 5.57 \\
\hline $\begin{array}{l}\text { George } \\
\text { Municipality }\end{array}$ & 2697 & 108375 & 3268 & 193672 & -3.14 & 3.72 \\
\hline $\begin{array}{l}\text { Drakenstein } \\
\text { Municipality }\end{array}$ & 1900 & 177093 & 2497 & 251262 & -1.21 & 1.33 \\
\hline $\begin{array}{l}\text { Overstrand } \\
\text { Municipality }\end{array}$ & 3265 & 37469 & 3459 & 80432 & -4.98 & 19.3 \\
\hline $\begin{array}{l}\text { Knysna } \\
\text { Municipality }\end{array}$ & 1557 & 42947 & 1726 & 68659 & -2.75 & 5.52 \\
\hline
\end{tabular}

In all instances, the formal residential areas increased significantly less in the period 1990-2014 compared to the population growth during 1996-2011. This is illustrated by the last column in Table 2 (growth factor) indicating the rate by which population growth exceeded residential growth. In Overstrand municipality, for example this means that the population grew 19.3 times more than the formal residential footprint of the municipality. Noteworthy from the results is the USI in all instances below zero, mainly due to the disproportionate population growth compared to residential expansion. What the results clearly indicate is the inability of the formal residential market (. i.e. the private sector and state-assisted housing schemes) to keep abreast the rapid population growth experienced by these municipalities. In response to rapid immigration, a large component of residential growth in South African happens in informal settlements, a development pattern that inadvertently contributes to urban sprawl. Based on this the analysis was performed again, this time including land use cover changes occurring as a result of as the growth of informal settlements. The results of the second analysis is presented in Table 3.

Table 3: USI calculated for population growth measured against existing residential and informal area for two reference years

\begin{tabular}{|l|r|r|r|r|l|l|}
\hline & Area 1990 & \multicolumn{1}{l|}{$\begin{array}{l}\text { Population } \\
\text { 1996 }\end{array}$} & Area 2014 & $\begin{array}{l}\text { Population } \\
\text { 2011 }\end{array}$ & USI & $\begin{array}{l}\text { Growth } \\
\text { Factor }\end{array}$ \\
\hline $\begin{array}{l}\text { Cape Town } \\
\text { Metropolitan } \\
\text { Municipality }\end{array}$ & 35171 & 2563095 & 39482 & 3740026 & -2.07 & 3.75 \\
\hline $\begin{array}{l}\text { George } \\
\text { Municipality }\end{array}$ & 2699 & 108375 & 3355 & 193672 & -3.04 & 3.24 \\
$\begin{array}{l}\text { Drakenstein } \\
\text { Municipality }\end{array}$ & 1909 & 177093 & 2559 & 251262 & -1.13 & 1.23 \\
\hline $\begin{array}{l}\text { Overstrand } \\
\text { Municipality }\end{array}$ & 3265 & 37469 & 3504 & 80432 & -4.93 & 15.66 \\
\hline $\begin{array}{l}\text { Knysna } \\
\text { Municipality }\end{array}$ & 1709 & 42947 & 1937 & 68659 & -2.65 & 4.49 \\
\hline
\end{tabular}

Table 3 reveals that even when including informal residential areas as a land use category in calculating urban expansion, the USI continues to suggest an absence of urban sprawl. One possible explanation for the reduction of the growth rate of residential area is that the population and built-up 
density increased over time (Sharifi et al, 2014). One of the questions Du Plessis et al (2015) explores in their research is to establish whether there is an indication of compaction or densification of the urban structure in South Africa since 1994. The study found that the City of Cape Town experienced an increase in density of up to 13 persons/ha and a population density per residential footprint change between 1996 and 2011 of 16.8 persons per ha, supporting at least the results of the analysis for the City of Cape Town. Recent research in the City of Cape Town found that since the approval of the Spatial Development Framework and its accompanying urban edge and densification policies (2005) the rate of land consumption have dropped precipitously from over 750 hectares per year to a new normal of 250 hectares per year (Anonymous source, personal communication 2016, August 24), affirming that the sprawl that have been historically vilified seems to have disappeared. Current estimates of informal development in Cape Town points to a density of up to 160du/ha (CoCT, 2017), further supporting the interpretation of these results.

Thus far however the analysis failed to account for non-residential land use categories that may have resulted in land consumption contributing to urban sprawl. Consequently, the analysis was repeated by including “commercial” and “industrial” land use category data for 1990 and 2014. The results of this analysis is presented in Table 4.

Table 4: USI calculated for population growth measured against existing residential area, informal area, commercial and industrial area for two reference years

\begin{tabular}{|c|c|c|c|c|c|c|}
\hline & Area 1990 & $\begin{array}{l}\text { Population } \\
1996\end{array}$ & Area 2014 & $\begin{array}{l}\text { Population } \\
2011\end{array}$ & USI & $\begin{array}{l}\text { Growth } \\
\text { factor }\end{array}$ \\
\hline $\begin{array}{l}\text { Cape Town } \\
\text { Metropolitan } \\
\text { Municipality }\end{array}$ & 45386 & 2563095 & 50963 & 3740026 & -2.07 & 3.74 \\
\hline $\begin{array}{l}\text { George } \\
\text { Municipality }\end{array}$ & 3292 & 108375 & 4113 & 193672 & -3.01 & 3.16 \\
\hline $\begin{array}{l}\text { Drakenstein } \\
\text { Municipality }\end{array}$ & 3414 & 177093 & 3628 & 251262 & -2.11 & 6.68 \\
\hline $\begin{array}{l}\text { Overstrand } \\
\text { Municipality }\end{array}$ & 3376 & 37469 & 3674 & 80432 & -4.87 & 12.99 \\
\hline $\begin{array}{l}\text { Knysna } \\
\text { Municipality }\end{array}$ & 1878 & 42947 & 2134 & 68659 & -2.64 & 4.39 \\
\hline
\end{tabular}

Table 4 illustrates that the contribution of non-residential land categories to urban sprawl is fairly limited. With the exception of Drakenstein municipality, appearing to have experienced significant growth in commercial and industrial land uses, the remaining four municipalities see the addition of these land use categories leaving their USI's virtually unchanged.

The results of the preceding analyses suggest a noticeable reduction in land consumption and could be indicative of densification inside the urban edge. If the amount of sprawl is used as one indicator to measure the success of urban edges as planning instruments to curb urban sprawl, the results of this analysis suggest that the urban edge may have contributed to the containment of urban expansion. 
Whilst the analysis clearly indicates the enormous difference experienced by all the municipalities in population growth measured against land development, it cannot account for the typology of urban development that did occur during this time period. Whilst land consumption may appear to be limited, it does not preclude that development associated with urban sprawl (i.e. low(er) density, cardependant, access controlled residential estates) actually occurred.

\section{Limitations/Assumptions}

A shortcoming of traditional density measures (see Du Plessis et al., 2015) that will also impact on urban sprawl analyses is its sensitivity to methodological issues around the delimitation of urban areas and population figures based on administrative boundaries.

The authors also recognise that this is not a compounded USI but that it focuses only on physical expansion of the formal residential footprint of urban areas compared to crude population growth, while there are many other factors such as leapfrogging, densification and infill that is important to take cognisance of when determining the extent of urban sprawl in an urban area.

\section{Conclusion}

One of the main reasons for the absence of cross city empirical comparisons is the absence of a common set of land-use or land-cover data at an appropriate scale for multiple time periods (Du Plessis et al., 2015). This research attempted to measure sprawl over comparable time periods in order to establish the extent of urban sprawl in the Metropolitan area of Cape Town measured against other municipalities in the Western Cape Province. The results indicated that whilst population have grown tremendously in all municipalities, the rate of land consumption have been limited resulting in an $\mathrm{USI} \leq 0$ in all instances. Some of the smaller cities tended to experience more rapid population increases compared to the City of Cape Town. The negative values of the USI's calculated in this research points toward increased numbers of people not catered for by the formal residential development market and instead, and possibly contributing towards increased densities in formal and informal residential settlements.

In academia no-one has provided straight answers to questions like what should be the built-up growth rate in a non-sprawling city or what should be the per capita land consumption in a non sprawling city and therefore measuring the extent of urban sprawl by using an USI should not be used as an absolute indicator of the prevalence of urban sprawl but can at best be indicative of trends for comparative purposes. Presently the application of the USI to cities in the Western Cape yields results that suggest the success of the Western Cape Provincial urban edge policy by limiting urban sprawl and reducing land consumption per capita. However, the results cannot preclude that land development and consumption that did occur does not constitute in some instances resemble the typology of development associated with urban sprawl. 


\section{References}

Bhatta, B. Saraswati, S. and Bandyopadhyay, D 2010, "Urban sprawl measurement from remote sensing data”, Applied Geography Vol 30, 2010, 731-740

City of Cape Town Metropolitan Municipality 2009, “Cape Town Spatial Development Framework”. Draft for Comment, Accessed online 2016-08-30 https://www.capetown.gov.za/en/sdf/Documents/SDF_Technical_Report_web.pdf

Donaldson, R, Van Niekerk, A, Du Plessis, D, and Spocter, M 2012, “Non-metropolitan growth potential of Western Cape Municipalities”, Urban Forum Vol 23, 2012, 367-391

Du Plessis, D.J, and Boonzaaier, I 2015, “The evolving spatial structure of South African cities: A reflection on the influence of spatial planning policies”, International Planning Studies, Vol 20, No 1-2, 87-111

Eigelaar-Meets, I 2018, "Internal migration in post-apartheid South Africa: The cases of the Western and Northern Cape”, Doctorate Dissertation, Stellenbosch University.

Ewing, R 1994, “Characteristics, causes and effects of sprawl: a literature review”, Environmental and Urban Studies Vol 21, No 2, 1-15

Feng, L, Du, P.J, Li, H, Zhu, L, 2014, Measurement of urban fringe sprawl in Nanjing between 1984 and 2010 using multidimensional indicators, Geographical Research, Vol 53, no 2, 184-198

Frenkel ,A, and Ashkenazi ,M 2008, “Measuring urban sprawl: how can we deal with it?” Environment and Planning B: Planning and Design Vol 35, 2008, 56-79

Gao, B, and Huang, Q, He, C, Sun, Z, and Zhang, D, 2016, How does sprawl differ across cities in China? A multi-scale investigation using nighttime light and census data, Landscape and Urban Planning, Vol 1, no 48, 89-98 doi: 10.1016/j.landurbplan.2015.12.006

Haferburg, C, and Obenbrugge, J 2003, Ambiguous Restructurings of Post-Apartheid Cape Town. (eds) London: Transaction Publishers

Harrison, P., Todes, A., \& Watson, V, 2008, Planning and Transformation: Learning from the Post-Apartheid Experience, London: Routledge

Horn, A 2010, "Telling Stories: A history of growth management in Gauteng Province, South Africa", European Spatial Research and Policy Vol 17, No, $42-52$

Jacobs, W, and Du Plessis, D.J 2016, “A Spatial Perspective of the Patterns and Characteristics of Main- and Substream Migration to the Western Cape, South Africa”, Urban Form Vol 27, 167

Jenks, M, and Burgess, R 2000, Compact cities: Sustainable urban forms for developing countries. London: E \& FN Spon

Jenks, M, Kozak, D, and Takkanon, P 2008, World cities and urban form: fragmented, polycentric, sustainable? New York: Routledge

Mander, U, Brebbia, C, and Tiezzi, E 2006, The sustainable city IV: urban regeneration and sustainability. Southhampton: WIT

Sharifi, A, Chiba, Y, Okamoto, K, Yokoyama, S, and Murayama, A 2014, “Can master planning control and regulate urban growth in Vientiane, Laos?”, Landscape and Urban Planning Vol 131, 2014, 1-13

Sinclair-Smith, K 2014, "Methods and considerations for determining growth boundaries - an evaluation of the Cape Town Experience”, Urban Forum Vol 25, 313-333

Soja, E 2000, Postmetropolis: critical studies of cities and regions. Oxford: Blackwell Publishers

Sutton, P 2003, “A scale-adjusted measure of "Urban Sprawl” using night time satellite imagery”, Remote Sensing of Environment, Vol 86, 2003, 353-369

Turok, I, and Watson, V 2001, "Divergent development in South African cities: Strategic challenges facing Cape Town”, Urban Forum Vol 12, 2, 119-138

Wang, H, Ning, X, Zhang, H, Liu, Y, and Yu, F, 2018, "Urban boundary extraction and urban sprawl measurement using high-resolution remote sensing images: a case study of China's provincial, The 
South African Journal of Geomatics, Vol. 7. No. 3, November 2018

International Archives of the Photogrammetry, Remote Sensing and Spatial Information Sciences, doi: 10.5194/isprs-archives-XLII-3-1713-2018

Western Cape Department of Environmental Affairs and Development Planning 2005, Provincial Urban Edge Guidelines, Accessed online 2016-08-31.

https://www.westerncape.gov.za/other/2006/11/page1_18_urban_edge_guidelines.pdf

Wilson, E.H, Hurd, J.D, Civco, D.L, Prisloe, S and Arnold, C 2003, "Development of a geospatial model to quantify, describe and map urban growth”, Remote Sensing of Enrironment, Vol 86, No 3, 275-285 